\title{
Relationship between induced phytoplankton blooms and the structure and dynamics of the free-living heterotrophic bacterial community
}

\author{
Itziar Lekunberri ${ }^{1,2, *}$, Thomas Lefort ${ }^{1}$, Cristina Romera-Castillo ${ }^{1}$, Clara Cardelús ${ }^{1}$, \\ Montserrat Coll-Lladó ${ }^{1}$, Clara Ruiz-González ${ }^{1}$, Cèlia Marrasé ${ }^{1}$, Josep M. Gasol ${ }^{1, *}$ \\ ${ }^{1}$ Departament de Biologia Marina i Oceanografia, Institut de Ciències del Mar-CSIC, Barcelona, Catalunya, Spain \\ ${ }^{2}$ Present address: Department of Marine Biology, University of Vienna, Althanstr. 14, 1090 Vienna, Austria
}

\begin{abstract}
Bacterial community activity and structure are thought to be directly or indirectly related to phytoplankton development and, in particular, to the phytoplankton species dominating specific algal blooms. To test this hypothesis, we performed a mesocosm experiment designed to generate blooms of different types of phytoplankton through the additions of silicate, urea and phosphorus to oligotrophic water from the Blanes Bay Microbial Observatory (NW Mediterranean). Over $10 \mathrm{~d}$ of incubation bacterial activity, bacterial abundance, nutrient composition and free-living bacterial community structure were monitored, as well as phytoplankton composition and the fluorescence characteristics of dissolved organic matter (DOM). While we found clear effects of the different nutrient additions on chlorophyll levels, bacterial production and the type of dominant DOM, bacterial abundance followed a similar pattern across different nutrient treatments, which deviated from that observed in the control. While phytoplankton composition in the treatment with added silicate evolved differently with respect to the other treatments, free-living bacterial community structure (as determined with DGGE) did not show conspicuous differences between treatments. Our results reveal that the changes in bacterial community composition were mostly due to the variation in grazing pressure with time, with a small contribution from changes in bottom-up nutrient supply mediated by the shifts in phytoplankton composition.
\end{abstract}

KEY WORDS: Nutrients $\cdot$ Phytoplankton $\cdot$ Bacterial diversity $\cdot$ Mesocosms

\section{INTRODUCTION}

Phytoplankton blooms are marked increases in algal abundance, reaching concentrations of millions of cells $\mathrm{ml}^{-1}$ and consisting typically of 1 or only a few species. These phenomena occur when light is not limiting and nutrients are available in excess. In coastal waters, algal blooms are commonly the result of recurrent spring stratification, but also occur sporadically following nutrient inputs (Rosenberg et al. 1990, Smayda 1990). Variation in nutrient regimes affects phytoplankton production, diversity and succession and also influences the overall structure of the microbial food web (Smayda \& Reynolds 2001, Cullen et al. 2002).

Previous studies have correlated increases in biomass of individual phytoplankton species with nutrient inputs to coastal regions (Smayda 1990, Hallegraeff 1993). Diatom growth has been reported to be dependent on silica availability (e.g. Allen et al. 2005), and urea is thought to potentially select for some cyanobacteria and dinoflagellates because they have been found to preferentially use this molecule as a nitrogen source (Glibert et al. 2008, Solomon et al. 2010). Other algae are adapted to low nutrient concentrations, and they might bloom after oppor- 
tunistic species have depleted nutrients. For example, blooms of the eukaryotic picoplankter Aureococcus anophagefferens occur mainly when nitrate and ammonium have decreased below detection limits (Keller \& Rice 1989, Smayda \& Villareal 1989).

Primary producers release dissolved organic carbon (DOC) that is consumed by bacteria (e.g. Bell 1983, Morán et al. 2002). Comparative studies have shown a dependence of bacterial abundances on chlorophyll a (chl a), suggesting control of bacterial abundance by the availability of resources derived from primary production (Bird \& Kalff 1984, Cole et al. 1988, Gasol \& Duarte 2000). Thingstad \& Lignell (1997) enumerated 5 factors that influence the growth of heterotrophic bacteria: (1) DOC, (2) inorganic phosphate, (3) organic/inorganic nitrogen, (4) protozoan predation and (5) lysis by viruses. Control by resources of bacterial abundance and activity is often named 'bottom-up control' in contrast to control by predation or lysis.

While many studies have shown that the specificity of a phytoplankton bloom is a consequence of the specific nutrients added (Berdalet et al. 1996, Arin et al. 2002), few have related this selection to shifts in bacterial community structure (see e.g. Schäfer et al. 2001, Pinhassi et al. 2006). Laboratory nutrient enrichment experiments show a phytoplankton response followed by changes in bacterioplankton community composition (Pinhassi et al. 2006, Allers et al. 2007), for example, diatom blooms tend to be followed by developments of Flavobacteria. Grossart et al. (2005) reported that diatom-associated bacteria mainly belonged to Flavobacteria-Sphingobacteria, whereas free-living bacteria were comprised mainly of members of the Roseobacter group of Alphaproteobacteria. Sapp et al. (2007a) found strong shifts in the bacterial communities (mainly within members of the Gammaproteobacteria) associated with different diatom species, although they did not generalise this observation for strict microalgae-bacteria specific associations (Sapp et al. 2007b). Garcés et al. (2007) found little correspondence between the species of dinoflagellate developing in blooms and their associated bacterial communities.

We conducted a mesocosm experiment during the summer season in Blanes Bay (NW Mediterranean) in which we generated phytoplankton blooms of different species composition by strongly altering nutrient conditions, in terms of both quality and quantity; as a consequence, we expected to observe changes in bacterioplankton community structure and function. Experimental studies have always shown that phosphorus is generally limiting in the NW Mediterranean (Thingstad et al. 1998, Pinhassi et al. 2006), particularly during the summer (Pinhassi et al. 2006). To avoid phosphorus limitation, phosphate was added to all tanks except the controls. The 3 enriched treatments included addition of $\mathrm{SiO}_{2}$ and $\mathrm{NO}_{3}{ }^{-}$, urea, and $\mathrm{PO}_{4}{ }^{3-}$ alone. We monitored phytoplankton composition and took daily samples to characterise the fluorescence of the dissolved organic matter (DOM), bacterial abundance, physiological status and activity, and bacterial community structure. In addition, we monitored the development of the heterotrophic nanoflagellate (HNF) community to explore the role of top-down control in determining bacterial population changes.

\section{MATERIALS AND METHODS}

\section{Experimental setting and design}

The mesocosm experiment was carried out with water collected from Blanes Bay (The Blanes Bay Microbial Observatory, NW Mediterranean), $1 \mathrm{~km}$ offshore of the city of Blanes, Spain. Eight 1001 tanks (4 treatments, 2 replicates) were filled with $200 \mu \mathrm{m}$ filtered seawater, treated in duplicate with different additions and incubated at in situ temperature $\left(19^{\circ} \mathrm{C}\right)$ with a $12 \mathrm{~h}$ photoperiod and $121.3 \pm 3.5(\mathrm{SD}) \mu \mathrm{mol}$ photons $\mathrm{m}^{-2} \mathrm{~s}^{-1}$ light intensity to simulate natural conditions. The first sampling was taken $1 \mathrm{~h}$ after nutrient additions. The experiment was conducted during $10 \mathrm{~d}$ from 5 to 15 June 2007.

Four treatments were set up: Treatment K (control) refers to no nutrient additions (tanks $\mathrm{K}_{\mathrm{a}}$ and $\mathrm{K}_{\mathrm{b}}$ ),

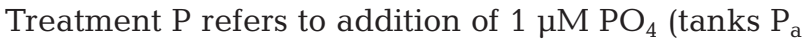
and $\mathrm{P}_{\mathrm{b}}$ ). Treatment $\mathrm{U}$ corresponds to additions of $1 \mu \mathrm{MPO}_{4}{ }^{3-}$ and $16 \mu \mathrm{M}$ urea $\left(\mathrm{CO}\left(\mathrm{NH}_{2}\right)_{2}\right.$, tanks $\mathrm{U}_{\mathrm{a}}$ and $\mathrm{U}_{\mathrm{b}}$ ), and Treatment Si refers to $1 \mu \mathrm{M} \mathrm{PO}_{4}{ }^{3-}, 16 \mu \mathrm{M}$ $\mathrm{NO}_{3}{ }^{-}$and $25 \mu \mathrm{M} \mathrm{SiO}_{2}$ (tanks $\mathrm{Si}_{\mathrm{a}}$ and $\mathrm{Si}_{\mathrm{b}}$ ). To keep the $\mathrm{SiO}_{2}$ in excess, we added it twice (on Days 0 and 1). Our goal was to add $\mathrm{Si}$ in a ratio P:N:Si of 1:16:25, higher than the standard Redfield value for Si (1:16:16) to make sure that the $\mathrm{SiO}_{2}$ was in excess. To all tanks we added a metal solution in the same proportion to $\mathrm{PO}_{4}{ }^{3-}$ as present in the $\mathrm{f} / 2$ medium (Guillard 1975). See Table 1 for the measured concentrations in the tanks after the additions.

\section{Micro-, pico- and nanoplankton enumeration}

For the identification of microphytoplankton (mainly diatoms, dinoflagellates and coccolithophorids), samples were fixed with formalin-hexamine solution 
Table 1. Concentrations of nutrients (mean $\pm \mathrm{SD}, \mu \mathrm{M}$ ) in the 4 different experimental conditions $1 \mathrm{~h}$ after the nutrient addition. Subscripts a and b represent the replicates. TDN: total dissolved nitrogen

\begin{tabular}{|c|c|c|c|c|c|}
\hline Experimental condition & Nomenclature & $\mathrm{PO}_{4}{ }^{3-}$ & $\mathrm{NO}_{3}^{-}$ & $\mathrm{SiO}_{2}$ & TDN \\
\hline Initial water & & 0.02 & 0.13 & 0.04 & - \\
\hline Control & $\mathrm{K}_{\mathrm{a}}, \mathrm{K}_{\mathrm{b}}$ & $0.02 \pm 0.00$ & $0.34 \pm 0.03$ & $0.38 \pm 0.02$ & $5.12 \pm 0.53$ \\
\hline Phosphorus & $\mathrm{P}_{\mathrm{a}}, \mathrm{P}_{\mathrm{b}}$ & $0.67 \pm 0.03$ & $0.4 \pm 0.05$ & $0.34 \pm 0.06$ & $6.92 \pm 1.51$ \\
\hline $\mathrm{NO}_{3}{ }^{-}+\mathrm{PO}_{4}{ }^{3-}+\mathrm{SiO}_{2}$ & $\mathrm{Si}_{\mathrm{a}}, \mathrm{Si}_{\mathrm{b}}$ & $0.75 \pm 0.01$ & $12.5 \pm 1.03$ & $22.7 \pm 0.79^{\mathrm{a}}$ & $16.04 \pm 0.47$ \\
\hline Urea+P & $\mathrm{U}_{\mathrm{a}}, \mathrm{U}_{\mathrm{b}}$ & $0.79 \pm 0.01$ & $0.31 \pm 0.01$ & $0.31 \pm 0.00$ & $17.83 \pm 3.17$ \\
\hline
\end{tabular}

( $0.4 \%$ final concentration). Counts were made with the methodology described by Utermöhl (1958), using $50 \mathrm{~cm}^{3}$ settling chambers. One transect of the chamber was observed at $400 \times$ magnification to count the smaller $(<20 \mu \mathrm{m})$ and more abundant organisms. Additionally, 1 transect of half of the chamber was inspected at $200 \times$ magnification to enumerate cells of intermediate size (roughly 20 and $50 \mu \mathrm{m}$ ), and the whole chamber was scanned at $200 \times$ magnification to count the large forms.

Determination of algal and bacterial abundance was performed with flow cytometry (Gasol \& del Giorgio 2000, Marie \& Partensky 2006). For phytoplankton, the samples were not fixed and were run at high speed (ca. $100 \mu \mathrm{min}^{-1}$ ). Four populations (Prochlorococcus, Synechococcus, picoeukaryotes and nanoeukaryotes) were differentiated according to size and red and orange fluorescence. For chemotrophic bacteria, $1.2 \mathrm{ml}$ samples were fixed with a $1 \%$ paraformaldehyde + $0.05 \%$ glutaraldehyde solution, and deep-frozen in liquid $\mathrm{N}_{2}$. Afterwards the samples, were thawed, stained with SYBRGreen at a 1:10 dilution and run at low speed (ca. $10 \mu \mathrm{min}^{-1}$ ). Cells were identified in a plot of side scatter versus green fluorescence.

HNF abundances were measured by flow cytometry following the protocol of Rose et al. (2004). From a stock solution of $1 \mathrm{mM}$ Lysotracker Green (Molecular Probes), $1 \mu \mathrm{l}$ was added to $99 \mu \mathrm{l}$ of $<0.2 \mu \mathrm{m}$ MilliQ, and $3.8 \mu \mathrm{l}$ of this diluted Lysotracker solution were added to $0.5 \mathrm{ml}$ of the sample, generating a $75 \mathrm{nM}$ Lysotracker final concentration. We analysed the samples, as in Rose et al. (2004), using a combination of side scatter and green and red fluorescence. Samples were run alive at high (ca. $100 \mu \mathrm{min}^{-1}$ ) speed. Concentrations were obtained from weight measurement of the volume analysed.

Two groups of heterotrophic bacteria were distinguished based on their relative green fluorescence (FL1, $530 \mathrm{~nm}$ ) as a proxy for nucleic acid content: a population with high (HNA) and 1 with low nucleic acid (LNA) content. Percent HNA indicates the counts of HNA bacteria with respect to the total.

\section{Excitation-emission matrices (EEM) of DOM fluorescence}

Samples were filtered through pre-combusted $\left(450^{\circ} \mathrm{C}, 4 \mathrm{~h}\right)$ Whatman GF/F filters in an acid-cleaned glass filtration system, under low $\mathrm{N}_{2}$-flow pressure. EEMs were performed, immediately after sample collection, with an LS 55 Perkin Elmer luminescence spectrometer, equipped with a Xenon discharge lamp, equivalent to $20 \mathrm{~kW}$ for $8 \mu$ s duration. The detector was a red-sensitive R928 photomultiplier, and a photodiode worked as a reference detector. Slit widths were $10.0 \mathrm{~nm}$ for the excitation (Ex) and emission (Em) wavelengths; scan speed was $250 \mathrm{~nm}$ $\min ^{-1}$. Measurements were performed at a constant room temperature of $20^{\circ} \mathrm{C}$ in a $1 \mathrm{~cm}$ quartz fluorescence cell. The matrices were generated by combining 25 synchronous Ex/Em fluorescence spectra of the sample, obtained for excitation wavelengths from 200 to $450 \mathrm{~nm}$ and an offset between the excitation and emission wavelengths of $20 \mathrm{~nm}$ for the first scan and $260 \mathrm{~nm}$ for the 25th scan. Raman scatter was corrected by subtracting the pure water (Milli-Q) EEM from the sample EEM. Fluorescence values are expressed in quinine sulphate units (QSU) to allow comparison with other studies.

\section{Bacterial single-cell activity and production}

Measurements of the different physiological states of bacteria were done in 2 ways: (1) We determined highly respiring prokaryotes as those able to reduce 5-cyano-2,3-diotolyl tetrazolium chloride (CTC; Polysciences). CTC turns into a red fluorescent formazan that is detectable by epifluorescence and flow cytometry (Sherr et al. 1999, Sieracki et al. 1999). Sample aliquots $(0.4 \mathrm{ml})$ were amended with $5 \mathrm{mM} \mathrm{CTC}$ (from a fresh stock solution at $50 \mathrm{mM}$ ) immediately following collection and were incubated for $90 \mathrm{~min}$ in the dark at room temperature. CTC-positive $\left(\mathrm{CTC}^{+}\right)$ cells were enumerated by flow cytometry using the 
FL2-versus-FL3 dot plot (see Gasol \& Arístegui 2007). For these analyses, we used a high speed (ca. $100 \mu \mathrm{l} \mathrm{min}{ }^{-1}$ ) and a threshold set in red fluorescence. (2) Cells with intact membranes were enumerated using the nucleic acid double-staining (NADS) viability protocol, based on the combination of the cell-permeant nucleic acid stain SYBRGreen I (SG1, Molecular Probes) and the cell-impermeant propidium iodine (PI, Sigma Chemical) fluorescent probe. We used 1:10 SG1 and $10 \mu \mathrm{g} \mathrm{ml}^{-1}$ PI concentrations. After simultaneous addition of each stain, the samples were incubated for $20 \mathrm{~min}$ in the dark at room temperature and then analysed by flow cytometry. SG1 and PI fluorescence were detected in the green (FL1) and orange-red (FL3) cytometric channels, respectively. A dot plot of red versus green fluorescence allowed distinction of the 'live' cell cluster (i.e. cells with intact membranes and DNA present) from the 'dead' cell one (i.e. with compromised membranes, Grégori et al. 2001, Falcioni et al. 2008).

Bacterial heterotrophic production was estimated using the ${ }^{3} \mathrm{H}$-leucine incorporation method (Kirchman et al. 1985). Quadruplicate aliquots of $1.2 \mathrm{ml}$ and 2 trichloroacetic acid(TCA)-killed controls were taken daily. The samples were incubated with $40 \mathrm{nM}$ ${ }^{3} \mathrm{H}$-leucine final concentration for about $2 \mathrm{~h}$ in the dark and at in situ temperature. The incorporation was stopped with the addition of $120 \mu$ of cold TCA $50 \%$ to each replicate, and the samples were kept frozen at $-20^{\circ} \mathrm{C}$ until processing, which was carried out by the centrifugation method described by Smith \& Azam (1992).

\section{Collection of community DNA and fingerprinting analysis}

Microbial biomass was collected by sequential filtration of about 51 of seawater through a $3 \mu \mathrm{m}$ pore size polycarbonate filter (Millipore, $46 \mathrm{~mm}$ ) to separate free-living bacteria from attached bacteria (Simon 1985) and a $0.2 \mu \mathrm{m}$ Sterivex filter unit (Millipore). Microbial biomass was collected in the Sterivex unit, treated with lysozyme, Proteinase $\mathrm{K}$ and sodium dodecyl sulphate, and the nucleic acids were extracted with phenol and concentrated in a Centricon-100 centrifugal device (Millipore). The nucleic acids were extracted by a standard protocol using phenol/ chloroform (Schauer et al. 2003).

Denaturing gradient gel electrophoresis (DGGE) and gel analysis were performed essentially as previously described (Schauer et al. 2000). Briefly, 16S
rRNA gene fragments (around $550 \mathrm{bp}$ in length) were amplified by PCR, using the universal primer $907 \mathrm{rm}$ and the bacteria-specific primer 358f, with a GCclamp. The PCR products were loaded on a $6 \%$ polyacrylamide gel with a DNA-denaturant gradient ranging from 40 to $80 \%$. The gel was run at $100 \mathrm{~V}$ for $16 \mathrm{~h}$ at $60^{\circ} \mathrm{C}$ in $1 \times$ TAE running buffer. DGGE gel images were analysed using the Diversity Database software (BIO-RAD).

Dominant DGGE bands were excised from the gel and kept in $20 \mu \mathrm{l}$ of MilliQ water overnight. Five $\mu \mathrm{l}$ of the supernatant were used for reamplification with the original primer set. A part of the PCR product was checked by DGGE together with the original sample to verify the correct position of the bands. PCR products were purified with the QIAquick PCR-Purification Kit (Qiagen) and quantified in an agarose gel. Approximately 10 to $20 \mathrm{ng}$ were used for the sequencing reaction, using primer $358 f$ without the GC-clamp, with the Bigdye Terminator Cycle Sequencing Kit v2.0 (PE Biosystems) and an ABI PRISM model 377 (v3.3) automated sequencer. The sequences obtained (normally between 400 and $500 \mathrm{bp}$ ) were compared with public database DNA sequences using BLAST, and submitted to GenBank under accession numbers HQ122945 to HQ122955.

\section{Statistical analyses}

A matrix was constructed for all DGGE lanes taking into account the relative contribution of each band (in percentage) to the total intensity of the lane (Quantity One, BIORAD). Based on this matrix, we obtained a dendrogram by the Ward's clustering method (Euclidean distances, Statistica 6.0) and ordinations of nonmetric multidimensional scaling (NMDS) based on the Bray-Curtis similarity index (Kruskal \& Wish 1979, Clarke \& Green 1988). A 1 -way analysis of similarity (ANOSIM) was computed to test the observed differences between treatments and the control samples over time and within treatment samples (software Primer v5).

We also used 1-way analyses of variance (ANOVAs) to test for the differences in chl $a$, bacterial abundance and bacterial activity between treatments at the different times when samples were taken for bacterial composition analyses. We tested the dependence of bacterial community structure on time with a Mantel test using the matrix of community composition and time and with the Relate function of the software PRIMER vs6. 


\section{RESULTS}

\section{Evolution of inorganic nutrient concentrations}

The initially added nutrients are shown in Table 1 , while variations of the inorganic nutrient concentrations for the different treatments during the experiment are shown in Fig. 1. Except for the control, all tanks had received $1 \mu \mathrm{MPO}_{4}{ }^{3-}$, which was rapidly consumed in the $\mathrm{N}$-amended treatments ( $\mathrm{Si}$ and $\mathrm{U}$ ) but remained quite high in the P-only tank. The $\mathrm{N}$ source in the Si tank was $\mathrm{NO}_{3}{ }^{-}$, which started to decrease on Day 6 (Fig. 1C). The maximal value of $\mathrm{SiO}_{2}$ (Fig. 1B) was only reached on Day $2(25 \mu \mathrm{M}$, after the second nutrient addition), and this concentration was only reduced to ca. $10 \mu \mathrm{M}$ at the end of the experiment, thus indicating that there was much unused $\mathrm{SiO}_{2}$ in this treatment. Silicate remained at the initial value of $0.4 \mu \mathrm{M}$ in the control treatment, but it was used down to values $<0.1 \mu \mathrm{M}$ in the urea treatment after Day 3, and in the P treatment after Day 5.

\section{Dynamics of chl a and phytoplankton composition}

The initial value of chl $a$ was around $0.2 \mathrm{mg} \mathrm{m}^{-3}$ in all tanks (Fig. 2A). Significant differences $(<0.05)$ between treatments were found after Day 3. The Si tank reached concentrations 16 -fold higher than the control and the P tank, while the U tanks reached values ca. 5-fold higher than those of the $\mathrm{K}$ and $\mathrm{P}$ tanks. In all tanks, chl a remained high until the end of the experiment. The maximum value of chl $a$ in the $\mathrm{P}$ and $\mathrm{K}$ tanks was reached on Day 2, in the U tank on Day 4 and in the Si tank on Day 6. Surprisingly, and in spite of the differences in nutrient treatments, the dominant phytoplankton species were similar under all experimental conditions. Among diatoms, the dominant species were Proboscia alata, Leptocylindrus spp., Guinardia flaccida, Nitzschia sp., PseudoNitzschia spp., small Chaetoceros $(<20 \mu \mathrm{m})$, Skeletonema costatum and Thalassionema nitzschoides. Among dinoflagellates, the dominant taxa were Torodinium robustum, Protoperidinium spp., Prorocentrum spp. and Gyrodinium spp. Most coccolithophorids could not be identified at the species level, and among the identified species, Syracosphaera pulcra was dominant. We did find differences, in terms of

Fig. 1. Nutrient evolution throughout the mesocosm experiment. (A) Phosphate, (B) silicate and (C) nitrate+nitrite. The arrow shows the day on which a second addition of silicate was made
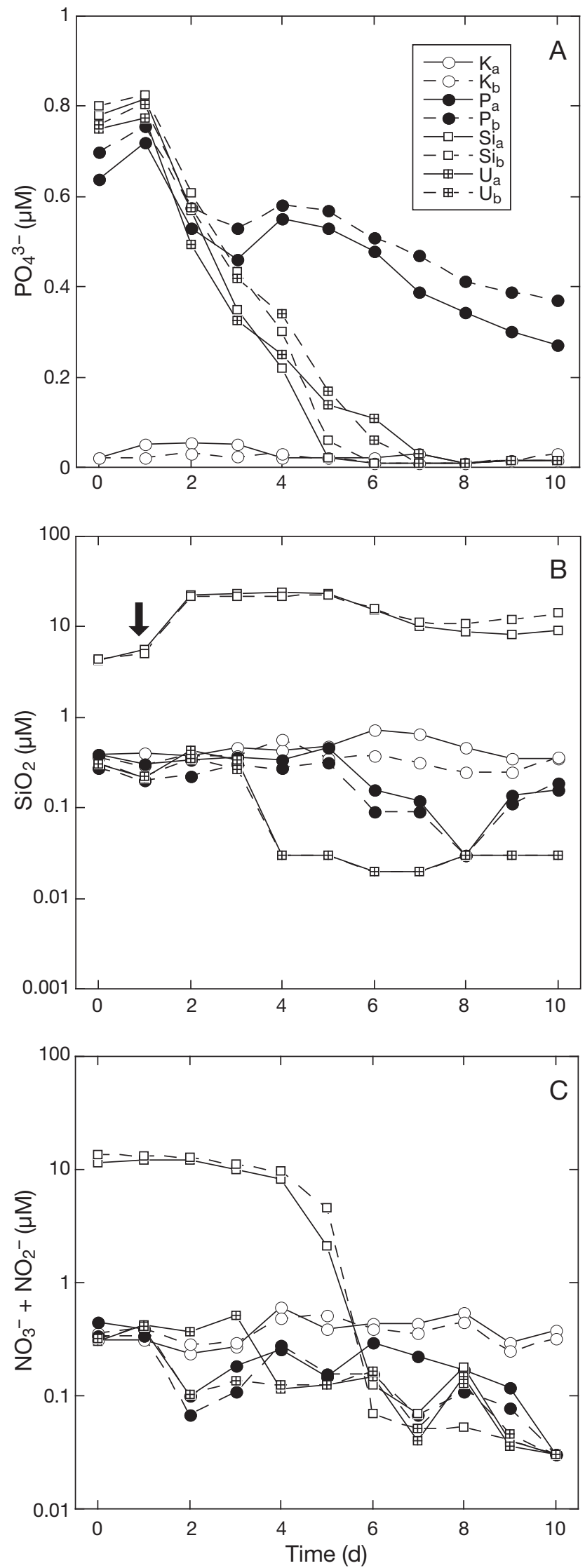

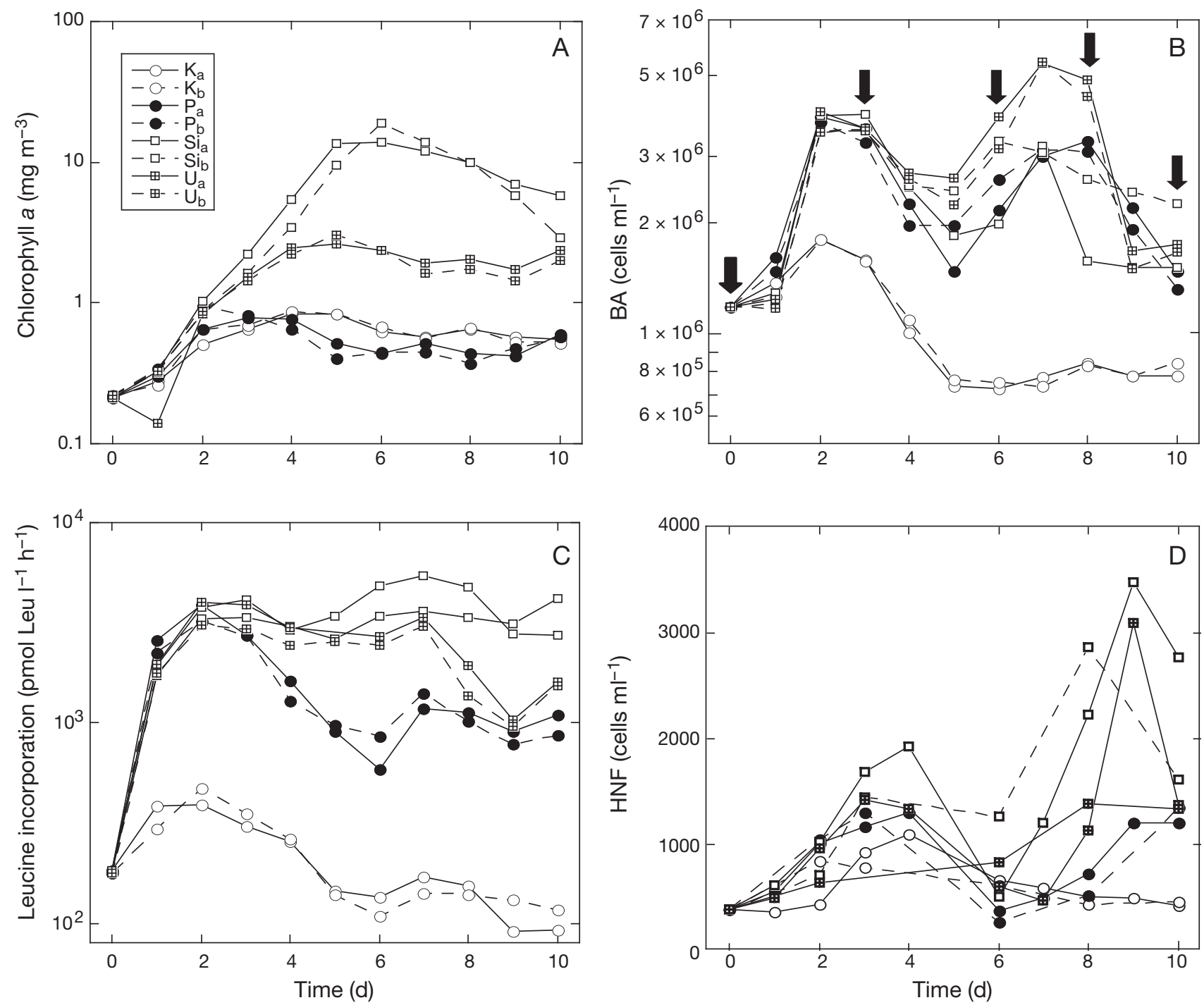

Fig. 2. (A) Chlorophyll a concentration, (B) bacterial abundance (BA), (C) leucine incorporation rates and (D) heterotrophic nanoflagellate (HNF) abundance throughout the mesocosm experiment. The arrows show the points where bacterial DNA was sampled

relative biomass proportion, from the beginning to the end of the experiment within each experimental condition (Table 2, and see Table S1 in the supplement at www.int-res.com/articles/suppl/m448 p023_supp.xls). The diatoms Nitzschia (41\% biovolume on average) and Proboscia (14\%) dominated the Si treatment, Gyrodimnium (27\%) and other diatoms dominated the U treatments, while Proboscia (25\%) alongside unidentified dinoflagellates $(12 \%)$ dominated the $\mathrm{P}$ treatment. The $\mathrm{K}$ treatment had almost equal contributions of nanoflagellates, Ceratium and unidentified dinoflagellates, but were dominated by Proboscia $(35 \%)$. The decrease in diatom contribution to biovolume in the $\mathrm{P}$ and, especially, in the $\mathrm{U}$ tanks noticeably coincided with $\mathrm{SiO}_{2}$ depletion
(Day 6). In contrast, and as expected, the contribution of diatoms in the Si tanks remained high during the whole experiment (Table 2).

On the basis of size and pigment content, we identified 2 different populations of picophytoplankton (Synechococcus and picoeukaryotes). Prochlorococcus were not present in Blanes Bay at this time of the year (details not shown). Synechococcus in the control and P treatments peaked on Day 3 and then decreased but maintained populations similar to the initial ones. The U and Si treatments had the highest values, with a peak on Day 5 and then decreased to disappearance at the end (Fig. 3A). Picoeukaryotes peaked on Day 4, with maximal values in the Si and U tanks (Fig. 3B). 
Table 2. Contribution to biovolume (\%) of the main microphytoplankton groups on Days 0, 3, 6, 8 and 10 under the different experimental conditions $(\mathrm{K}, \mathrm{Si}, \mathrm{U}$ and $\mathrm{P})$

\begin{tabular}{|c|c|c|c|c|c|}
\hline & Day 0 & Day 3 & Day 6 & Day 8 & Day 10 \\
\hline \multicolumn{6}{|l|}{ Control (K) } \\
\hline Dinoflagellates & 24.3 & 30.2 & 48.4 & 39.8 & 42.4 \\
\hline Diatoms & 70.7 & 63.1 & 41.7 & 50.5 & 45.6 \\
\hline Coccolithophorids & 1.3 & 1.8 & 4.1 & 2.8 & 3.9 \\
\hline Others & 3.7 & 5.0 & 5.8 & 6.9 & 8.0 \\
\hline \multicolumn{6}{|c|}{ Silicate/nitrate/phosphate addition (Si) } \\
\hline Dinoflagellates & 24.3 & 21.7 & 7.7 & 25.4 & 27.2 \\
\hline Diatoms & 70.7 & 71.2 & 86.7 & 72.3 & 71.4 \\
\hline Coccolithophorids & 1.3 & 1.6 & 0.7 & 0.2 & 0.1 \\
\hline Others & 3.7 & 5.5 & 5.0 & 2.1 & 1.3 \\
\hline \multicolumn{6}{|c|}{ Urea/phosphate addition (U) } \\
\hline Dinoflagellates & 24.3 & 41.2 & 47.0 & 63.9 & 61.6 \\
\hline Diatoms & 70.7 & 54.0 & 48.4 & 30.7 & 23.9 \\
\hline Coccolithophorids & 1.3 & 0.8 & 1.6 & 0.5 & 0.5 \\
\hline Others & 3.7 & 4.1 & 3.0 & 4.9 & 14.1 \\
\hline \multicolumn{6}{|c|}{ Phosphate addition (P) } \\
\hline Dinoflagellates & 24.3 & 34.0 & 41.8 & 53.3 & 49.0 \\
\hline Diatoms & 70.7 & 61.4 & 53.7 & 44.3 & 45.1 \\
\hline Coccolithophorids & 1.3 & 1.2 & 1.7 & 0.6 & 0.4 \\
\hline Others & 3.7 & 3.4 & 2.8 & 1.8 & 5.5 \\
\hline
\end{tabular}

\section{Fluorescence EEMs}

The EEMs were used to identify differences in the organic matter field caused by the different algae growing in the different treatments (Fig. 4). At the start of the experiment (T0) and on Day 5 (T5), all EEMs presented a conspicuous peak in the proteinlike region (peak-T defined by Coble et al. 1998 at Ex/Em 275/340 nm). At T0, this peak was centred at Ex/Em 290/352 nm, and it was higher and slightly shifted at longer excitation wavelengths at $\mathrm{T} 5$ for all treatments. The incubations amended with phosphorous (P) showed the highest intensity of fluorescence in this peak, followed by the urea treatment (U). In the visible humic-like region defined by Coble et al. (1998) at Ex/Em 320 to $360 / 420$ to $460 \mathrm{~nm}$, the EMM at T0 showed a marked peak at Ex/Em 345/448 nm corresponding to the so-called 'peak- $\mathrm{C}$ '. This peak was almost negligible in the control treatment $(\mathrm{K})$ at T5 but increased in intensity in the other 3 treatments. The tanks treated with nitrate and silicate $\left(\mathrm{SiO}_{2}\right)$ and those with urea (U) showed another peak at Ex/Em 354/447 nm and Ex/Em 350/450 nm, not visible in the other treatments.

Fig. 4 and Table 2 indicate that we were successful at creating differences in phytoplankton composition as well as in the organic matter field generated by the planktonic community, although we had expected more contrasting differences given the large differences in nutrient additions.
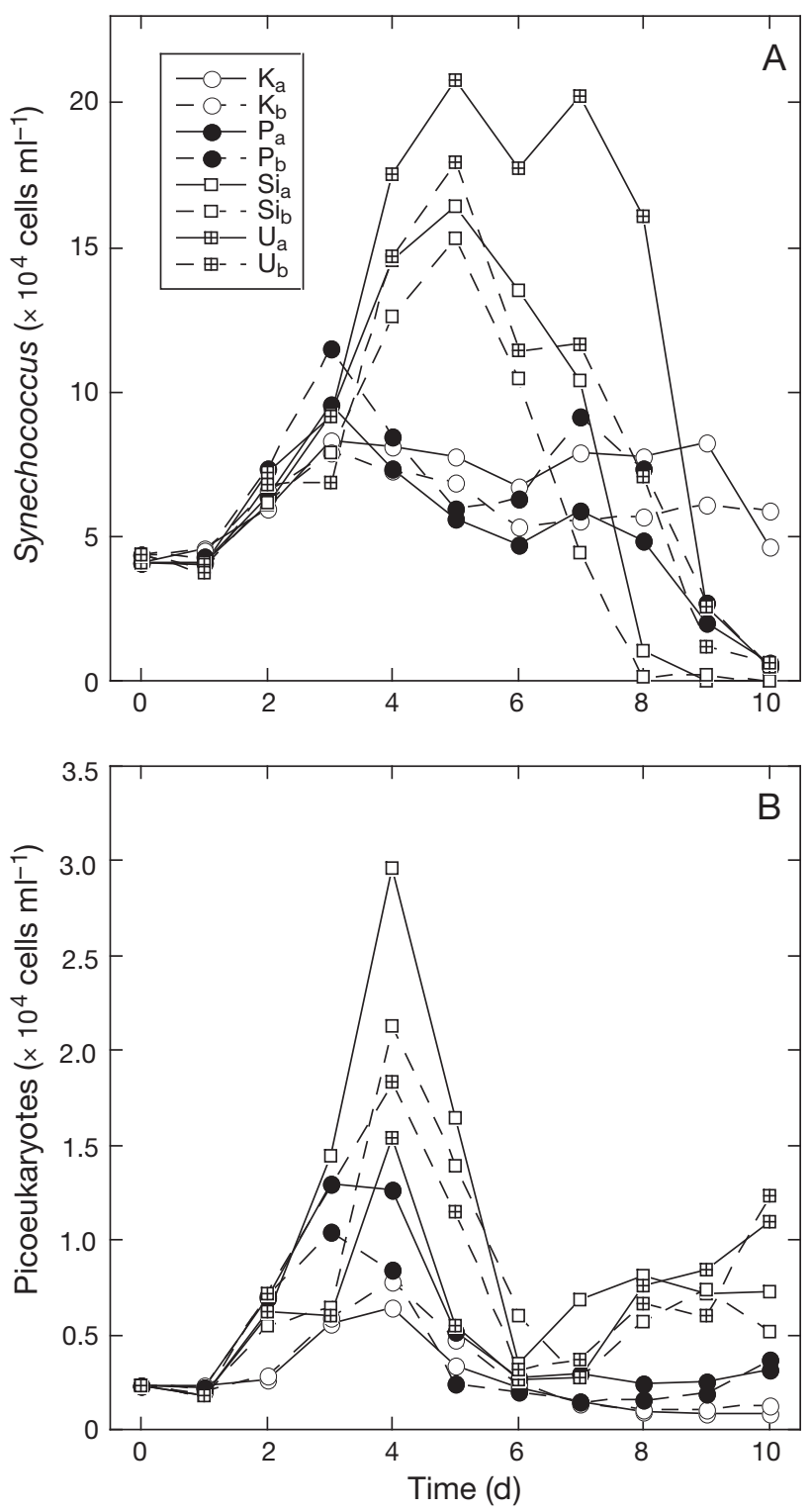

Fig. 3. Evolution of (A) Synechococcus and (B) picoeukaryotes throughout the mesocosm experiment

\section{Bacterial abundance and production}

Initial bacterial cell numbers were $1.2 \times 10^{6}$ cells $\mathrm{ml}^{-1}$ (Fig. 2B). There was an initial peak on Days 2 to 3 in all treatments, which was much larger in treatments $\mathrm{P}, \mathrm{U}$ and $\mathrm{Si}$ than in the control. A second peak on Days 6 to 8 did not occur in the control. This second peak was higher in the $\mathrm{U}$ treatment than in the $\mathrm{Si}$ and $\mathrm{P}$ treatments. There were significant differences (1-way ANOVA, p $<0.01$, Table 3) between controls and amended tanks at the beginning (Day 3) of the experiment.

All treatments presented an increase in bacterial production on Days 2 to 3, but no significant dif- 

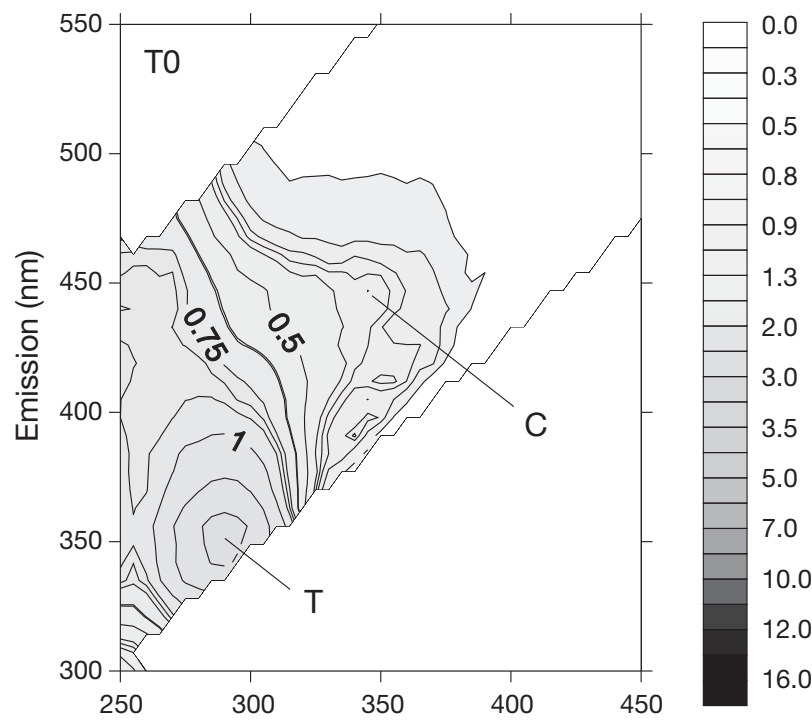

Fig. 4. Excitation-emission matrices of the fluorescent dissolved organic matter measured on Day 0 (T0, control only) and in all the treatments on Day 5: $\mathrm{K}_{\mathrm{a}}, \mathrm{P}_{\mathrm{a}}, \mathrm{Si}_{\mathrm{a}}$ and $\mathrm{U}_{\mathrm{a}}$. The matrices are expressed in quinine sulphate units (QSU). Peak $\mathrm{T}$ is defined at excitation/emission (Ex/Em) 275/340 $\mathrm{nm}$ and peak $\mathrm{C}$ corresponds to Ex/Em 345/448 nm
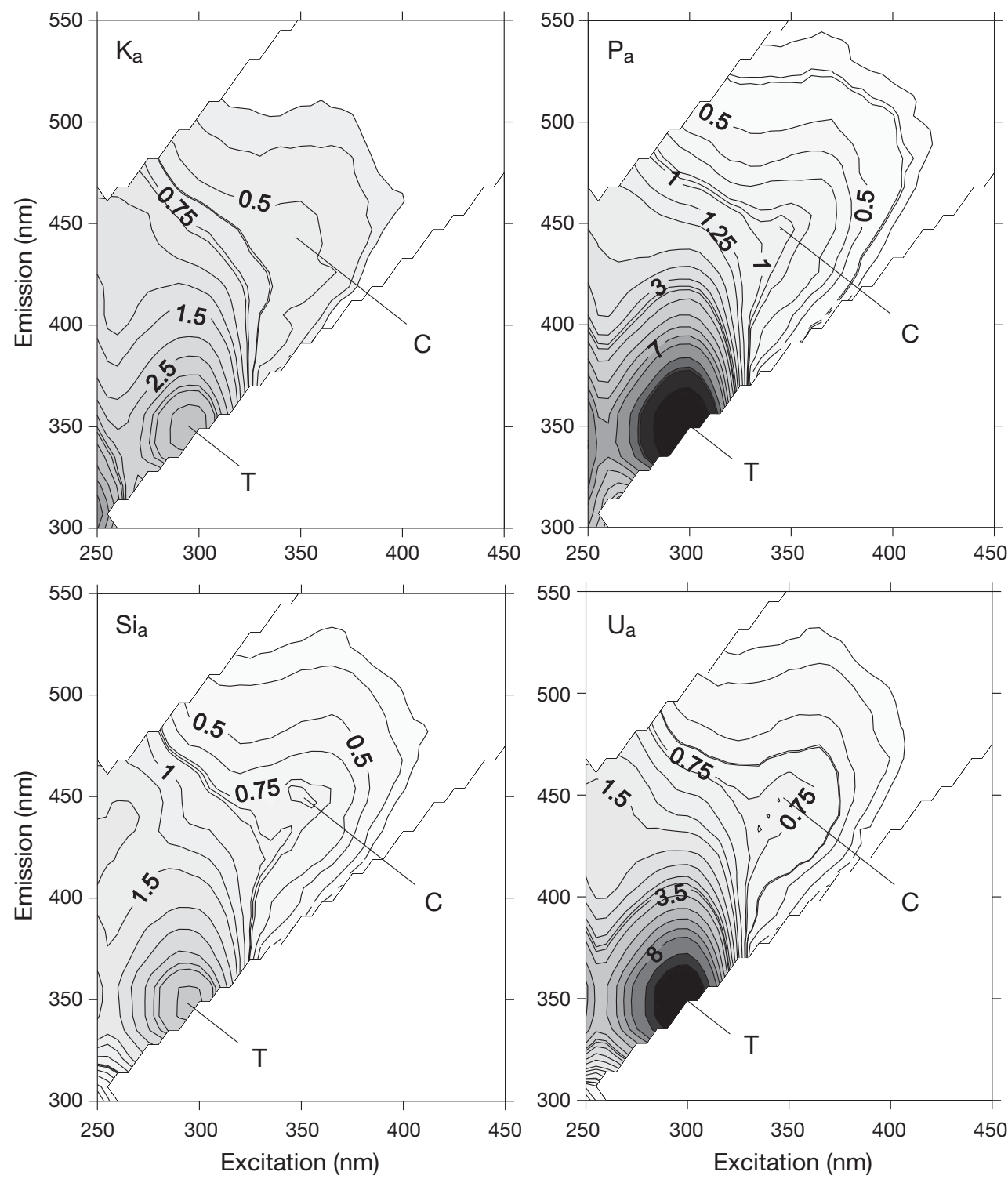
Table 3. Results of 1-way analyses of variance from Day 3 onwards, done at every time point when DNA samples were taken for the denaturing gradient gel electrophoresis analysis. $\mathrm{N}=2$ for all mesocosm experiments. Significant $(\mathrm{p}<$ 0.05) effects are in bold. Uppercase letters show the results of post hoc Student's $t$ pairwise comparisons. Treatments with different letters are significantly different. CTC: 5cyano-2,3-diotolyl tetrazolium chloride, ns: not significant

\begin{tabular}{|c|c|c|c|c|c|}
\hline & & Day 3 & Day 6 & Day 8 & Day 10 \\
\hline \multicolumn{6}{|c|}{ Chlorophyll a } \\
\hline & $\mathrm{p}$ & 0.011 & 0.002 & $<0.0001$ & 0.058 \\
\hline $\mathrm{K}$ & & A & A & A & A \\
\hline $\mathrm{P}$ & & A & A & A & A \\
\hline $\mathrm{Si}$ & & $\mathrm{B}$ & $\mathrm{B}$ & B & $\mathrm{B}$ \\
\hline $\mathrm{U}$ & & B & A & $\mathrm{C}$ & $\mathrm{AB}$ \\
\hline \multicolumn{6}{|c|}{ Bacterial abundance } \\
\hline & $\mathrm{p}$ & $<0.0001$ & 0.031 & 0.003 & ns \\
\hline $\mathrm{K}$ & & A & A & A & A \\
\hline $\mathrm{P}$ & & B & B & B & $A B$ \\
\hline $\mathrm{Si}$ & & B & B & B & B \\
\hline $\mathrm{U}$ & & B & B & $\mathrm{C}$ & B \\
\hline \multicolumn{6}{|c|}{ Bacterial production } \\
\hline & $\mathrm{p}$ & 0.004 & 0.004 & 0.008 & 0.01 \\
\hline $\mathrm{K}$ & & A & A & A & A \\
\hline $\mathrm{P}$ & & B & A & $\mathrm{AB}$ & $\mathrm{AB}$ \\
\hline $\mathrm{Si}$ & & B & B & $\mathrm{C}$ & $\mathrm{C}$ \\
\hline $\mathrm{U}$ & & B & $\mathrm{C}$ & B & B \\
\hline \multicolumn{6}{|c|}{ CTC + cell abundance } \\
\hline & $\mathrm{p}$ & 0.009 & 0.01 & 0.001 & ns \\
\hline $\mathrm{K}$ & & A & $\mathrm{A}$ & $\mathrm{A}$ & $\mathrm{A}$ \\
\hline $\mathrm{P}$ & & B & B & B & $\mathrm{A}$ \\
\hline $\mathrm{Si}$ & & B & $\mathrm{BC}$ & $\mathrm{C}$ & $\mathrm{A}$ \\
\hline $\mathrm{U}$ & & B & $\mathrm{C}$ & D & A \\
\hline
\end{tabular}

ferences were found between the amended tanks (Fig. 2C). At the beginning, they were all very different from the control tank. While the activity in the Si treatment maintained a high value throughout the experiment, activity decreased on Day 3 in the $\mathrm{P}$ treatment, and on Day 7 in the U treatment.

\section{HNF}

HNF abundances generally followed the changes in bacterial abundances, reaching highest values always at least $1 \mathrm{~d}$ after the peak of bacterial abundances (Fig. 2D). The first maximum occurred on Days 3 to 4 , and a second peak on Day 9. The first peak did not show strong differences between treatments, with a slightly higher value for treatment Si. The second peak was higher for treatments Si and U. The ratio bacteria:HNF, indicative of the predatory pressure of HNF on bacteria (e.g. Gasol 1994), was ca. 400 bacteria per HNF in the K treatment, and was maintained below 1000 in all treatments except in the $\mathrm{P}$ and $\mathrm{U}$ treatments on Days 6 to 8 (>2000 bacteria per HNF, details not shown). Values of this ratio near or below 1000 indicate a high predation pressure, while high values indicate relaxation of the pressure. The relaxation of the predation pressure in the $\mathrm{P}$ and $\mathrm{U}$ tanks coincided with the decrease in HNF abundance observed on Day 6 (Fig. 2D). Constantly high predation pressure agrees with the observed maintained high bacterial production (Fig. 2C) in the absence of continuous net growth beyond Day 2 (Fig. 2B).

\section{Bacterial single-cell activity}

All of the amended treatments presented a significantly $(\mathrm{p}<0.05)$ higher number of respiring cells compared to the controls (Fig. 5A, Table 2). The $\mathrm{U}$ tanks showed the highest number of respiring cells, followed by the $\mathrm{Si}$ and then the $\mathrm{P}$ tanks. The $\%$ NADS, which is another indicator of the physiological stage of the bacteria, did not show differences between treatments except for the controls, which decreased from Day 4 towards the end of the experiments (Fig. 5B). Differences between treatments were also observed by measuring the percentage of high nucleic acid containing bacteria (Fig. 5C), which showed almost exactly the same pattern as that of the amount of $\mathrm{CTC}^{+}$cells (Fig. 5A).

\section{Bacterial community composition and estimates of diversity}

DNA samples were collected on Days 0, 3, 6, 8 and 10. The analysis of the bacterial DGGE fingerprints (Fig. 6A) by the Ward's clustering method (Fig. 6B) and that of the NMDS (Fig. 6C) show similar results: the samples are organised by time rather than by treatment, thus indicating that the internal evolution in the tanks superseded the effects of the additions and those of the dominant phytoplankton species developing. The 1-way ANOSIM showed that the samples from treatments clustered together by timing $(\mathrm{R}=0.517, \mathrm{p}=0.003)$ and were different from the control samples $(\mathrm{R}=0.549, \mathrm{p}=0.002)$. The DGGE gel showed a higher number of bands (average: 15 bands) in the control samples as compared to the rest of the samples (average: 8 bands). In the different treatments there was a clear dominance of certain bands (1,8 and 9) during the first days of sampling (T3 and T6). Two of these dominant bands belong to the Alphaproteobacteria subclasses Rhodobacteraceae 

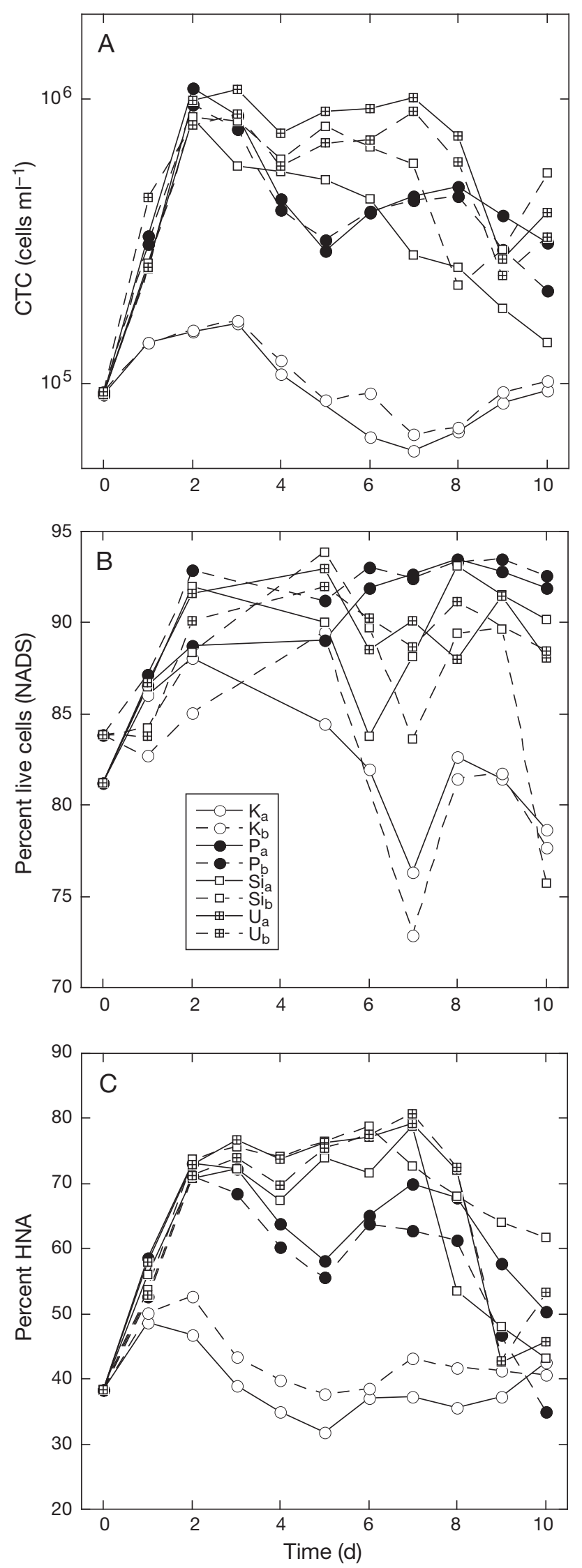

Fig. 5. Measures of single-cell bacterial activity. (A) 5cyano-2,3-diotolyl tetrazolium chloride (CTC)-positive cell abundance, (B) percentage of nucleic acid double-stained (NADS)-determined live cells and (C) percent high nucleic acid (HNA) bacteria

(1) and Rhodospirillaceae (8), and the Gammaproteobacteria subclass Oceanospirallaceae (9) (Table 4). No clear differences between treatments were found, and not a single dominant band could be associated with the Si or U treatments. Only the P treatment had 2 specific bands, 1 Gammaproteobacteria and 1 Bacteroidetes.

\section{DISCUSSION}

By adding different nutrients to a NW Mediterranean plankton community, we expected to generate differences in phytoplankton biomass levels and in phytoplankton community structure and diversity. As a consequence, we expected to generate changes in bacterial biomass, in bacterial function and in bacterial community diversity and structure. We observed changes in phytoplankton biomass (Figs. 2 \& 3), phytoplankton community structure (Table 2) and in the characteristics of the DOM present in the water (Fig. 4). However, for bacteria, we only observed large changes in activity (Fig. 2C), with little change in bacterial abundances (Fig. 2B). Bacterial community structure varied mainly over time, and much less between the different nutrient additions (Fig. 6).

Our study area (NW Mediterranean) is known to be phosphorus-limited, mainly during the summer (Thingstad et al. 1998, Pinhassi et al. 2006). As the experiment was carried out in June, and to avoid P limitation, all treatments except for the control ( $\mathrm{K}$ tank) were amended with phosphate $\left(\mathrm{PO}_{4}{ }^{3-}\right)$ at $1 \mu \mathrm{M}$ final concentration. In the tanks where only phosphorus was added, it was mostly unused, probably because of lack of an additional $\mathrm{N}$ source. In this treatment, we expected development of picoeukaryotes and small algae (Agawin et al. 2004). However, the phytoplankton composition in the $\mathrm{P}$ tanks did not vary much throughout the experiment (Table 2). This might indicate that 1 nutrient addition was not enough to promote the selection of a specific algal group as there was co-limitation (Fig. 1A). In the U tanks, urea was added as an organic nitrogen source. Our interest in the urea addition arose because it has been suggested that urea enrichment could preferentially lead to the dominance of cyanobacteria, picoeukaryotes and 

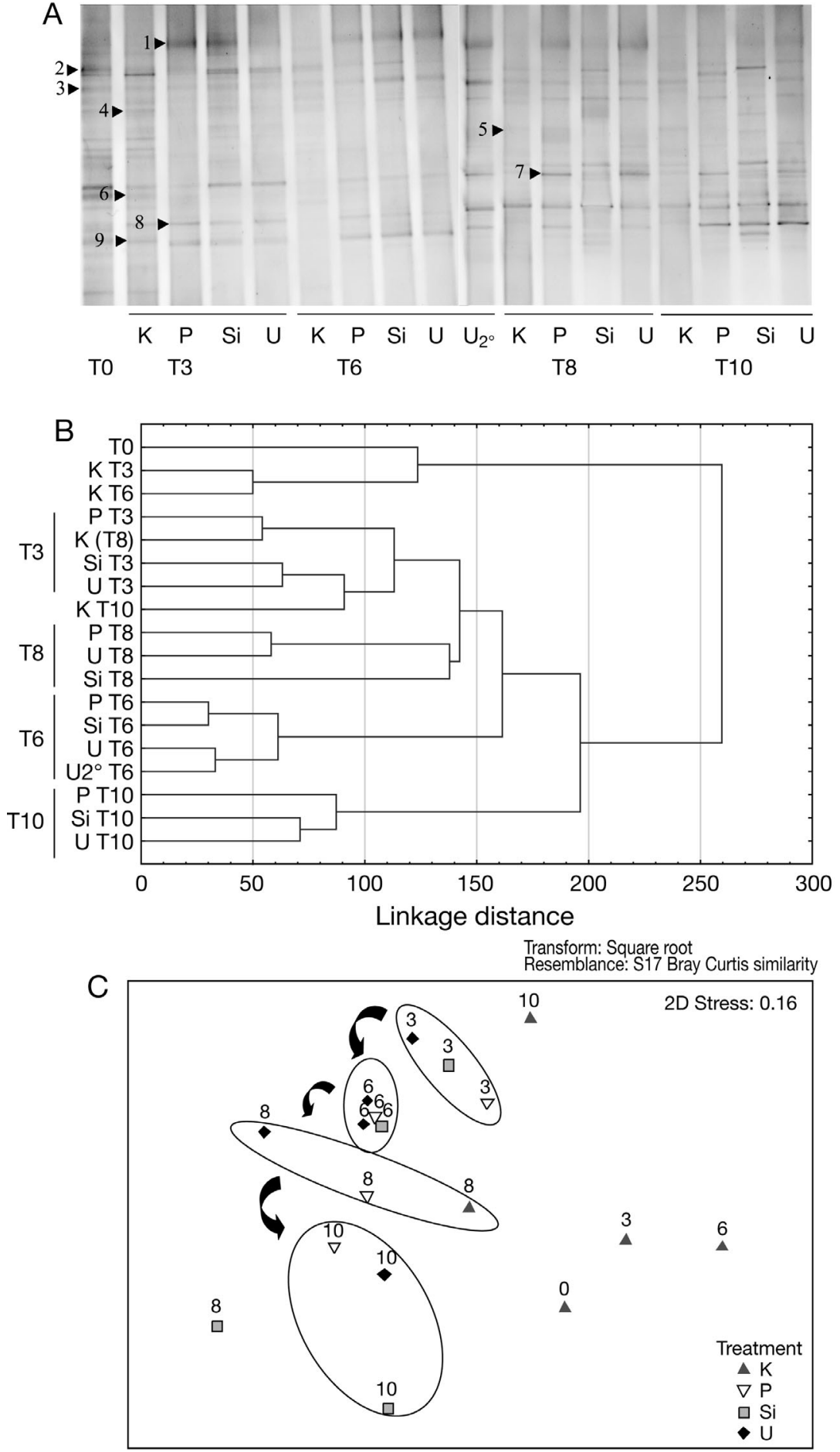

Fig. 6. (A) Denaturing gradient gel electrophoresis of bacterial 16S rRNA gene fragments from samples of different treatments and at different times of incubation. 1 to 9 identify extracted bands shown in Table 4. Sampling times were on Days 0 (T0), 3 (T3), 6 (T6), 8 (T8) and 10 (T10). Two different gels are presented, and 1 lane (U T6) is present in both gels. (B) Dendrogram classification (Ward's Method, Euclidean distances according to the band pattern) of DNA samples. (C) Nonmetric multidimensional scaling of the bacterial assemblage composition data. The arrows and grouping of samples by sampling days both facilitate understanding of the changes in community structure dinoflagellates (Glibert et al. 2008, and references therein). We observed an increase in dinoflagellates towards the end (Table 2), and Synechococcus reached values higher than in the other treatments from Day 5 to Day 9 (Fig. 3). The Si tanks were amended with $\mathrm{NO}_{3}{ }^{-}$ as a nitrogen source, and also $\mathrm{SiO}_{2}$ was added to promote diatom dominance. In this treatment, the chl a concentrations reached were 14-fold higher than in the other treatments (Fig. 2A), and phytoplankton was clearly dominated by diatoms (Table 2). In summary, we induced changes in phytoplankton species by different nutrient additions, but these were particularly clear in the Si treatment, while the $\mathrm{P}$ and $\mathrm{U}$ treatments evolved rather similarly, with clear-cut differences only after Day 6 (Table 2).

Phytoplankton growth and production can substantially affect the characteristics of the organic matter field (e.g. Myklestad 2000), and in some cases organic matter supply clearly determined bacterial community structure (e.g. Tada et al. 2011). Therefore, we measured DOM composition. Since this is a difficult task, due to the diversity and the low concentration of the substances that make up the DOM pool, we analysed the optical properties of the DOM (i.e. fluorescence) as a simple and fast way of distinguishing between different kinds of compounds. It has been used to track biogeochemical processes and has been applied to the study of the different compounds produced by phytoplankton and bacteria (Romera-Castillo et al. 2010, 2011). This technique allows us to explicitly test whether 2 samples have the same 'organic matter field', in a way analogous to the fingerprinting of bacterial community structure. The EEMs of DOM fluorescence at T0 and T5 allowed us to estimate differences in DOM quality just before the first and second bacterial peak, respectively. We found differences between the phosphorusamended treatments $(\mathrm{P})$ and the treatments amended with nitrogen. In a previous study with axenic phytoplank- 
Table 4. Phylogenetic affiliation of the 16S rRNA gene sequences of excised denaturing gradient gel electrophoresis bands obtained in the different treatments. For each phylotype, we show the closest relative sequence and culture as given by GenBank, together with their accession numbers and sequence similarity. We also indicate whether the phylotype was detected in the P, Si or U treatments. Alpha: Alphaproteobacteria; Gamma: Gammaproteobacteria

\begin{tabular}{|c|c|c|c|c|c|c|c|c|c|c|}
\hline $\begin{array}{l}\text { Band } \\
\text { ID }\end{array}$ & $\begin{array}{l}\text { Accession } \\
\text { no. }\end{array}$ & $\mathrm{K}$ & $\mathrm{P}$ & $\mathrm{Si}$ & $\mathrm{U}$ & Closest relative & $\begin{array}{l}\text { Accession } \\
\text { no }\end{array}$ & $\begin{array}{l}\text { Percent } \\
\text { similarity }\end{array}$ & Family & Subclass \\
\hline 1 & HQ122945 & $\mathrm{x}$ & $\mathrm{x}$ & $\mathrm{x}$ & $\mathrm{x}$ & $\begin{array}{l}\text { Uncultured bacterium } \\
\text { Rhodobium marinum }\end{array}$ & $\begin{array}{l}\text { AB449923 } \\
\text { D0791 }\end{array}$ & $\begin{array}{l}97 \\
78\end{array}$ & Rhodobacteraceae & Alpha \\
\hline 2 & HQ122946 & $\mathrm{x}$ & & $\mathrm{x}$ & $\mathrm{x}$ & Uncultured bacterium & AB449923 & 91 & Rhodobacteraceae & Alpha \\
\hline 3 & HQ122947 & $\mathrm{x}$ & $\mathrm{x}$ & $\mathrm{x}$ & $\mathrm{x}$ & $\begin{array}{l}\text { Uncultured alpha proteobacterium } \\
\text { Kordiimonas gwangyangensis }\end{array}$ & $\begin{array}{l}\text { AM238569 } \\
\text { AY682384 }\end{array}$ & $\begin{array}{l}98 \\
81\end{array}$ & Kordiimonadales & Alpha \\
\hline 4 & HQ122948 & $\mathrm{x}$ & & $\mathrm{x}$ & & $\begin{array}{l}\text { Uncultured bacterium } \\
\text { Ochrobactrum gallinifaecis }\end{array}$ & $\begin{array}{l}\text { FJ745197 } \\
\text { AJ51993 }\end{array}$ & $\begin{array}{l}99 \\
83\end{array}$ & Brucellaceae & Alpha \\
\hline 5 & HQ122949 & $\mathrm{x}$ & $\mathrm{x}$ & $\mathrm{x}$ & $\mathrm{x}$ & $\begin{array}{l}\text { Uncultured bacterium } \\
\text { Pseudomonas trivialis }\end{array}$ & $\begin{array}{l}\text { EU802695 } \\
\text { NR028987 }\end{array}$ & $\begin{array}{l}91 \\
78\end{array}$ & Pseudomonadaceae & Gamma \\
\hline 6 & HQ122952 & $\mathrm{x}$ & $\mathrm{x}$ & $\mathrm{x}$ & $\mathrm{x}$ & $\begin{array}{l}\text { Uncultured bacterium } \\
\text { Neptuniibacter caesariensis MED92 }\end{array}$ & $\begin{array}{l}\text { FJ202983 } \\
\text { AY136116 }\end{array}$ & $\begin{array}{l}97 \\
94\end{array}$ & Oceanospirallaceae & Gamma \\
\hline 7 & HQ122953 & & $\mathrm{x}$ & & & $\begin{array}{l}\text { Bacterium IS6 } \\
\text { Neptuniibacter caesariensis MED92 }\end{array}$ & $\begin{array}{l}\text { AY967730 } \\
\text { AY136116 }\end{array}$ & $\begin{array}{l}99 \\
97\end{array}$ & Oceanospirallaceae & Gamma \\
\hline 8 & HQ122954 & $\mathrm{x}$ & $\mathrm{x}$ & $\mathrm{x}$ & $\mathrm{x}$ & $\begin{array}{l}\text { Uncultured alpha proteobacterium } \\
\text { Skermanella xinjiangensis }\end{array}$ & $\begin{array}{l}\text { GQ346806 } \\
\text { EU586202 }\end{array}$ & $\begin{array}{l}98 \\
89\end{array}$ & Rhodospirillaceae & Alpha \\
\hline 9 & HQ122955 & $\mathrm{x}$ & $\mathrm{x}$ & $\mathrm{x}$ & $\mathrm{x}$ & $\begin{array}{l}\text { Neptuniibacter sp. } \\
\text { Neptuniibacter caesariensis MED92 }\end{array}$ & $\begin{array}{l}\text { GQ131677 } \\
\text { AY136116 }\end{array}$ & $\begin{array}{l}99 \\
98\end{array}$ & Oceanospirallaceae & Gamma \\
\hline
\end{tabular}

ton cultures (Romera-Castillo et al. 2010), the differences in DOM fluorescence were also related to changes in algal community structure.

We observed P limitation of the microbial community based on the differences in bacterial abundance and activity between the control tanks and the other treatments that had received phosphate. This strong limitation, well known from other studies (Thingstad et al. 1998, Sala et al. 2002, Pinhassi et al. 2004, 2006, and references therein), is what drove the initial evolution of the bacterial community, in response to the nutrient additions. Afterwards, HNF developed (Fig. 2D) and lowered the concentration of bacteria with a subsequent second bacterial peak (Fig. 2B,D), although this time some differences were observed in abundance and activity between treatments. For example, the differences in highly respiring cells as shown by the $\mathrm{CTC}^{+}$cell counts were visible in the $\mathrm{U}$ and Si tanks, although only the Si tank differed from the rest in bacterial production.

Bacterial abundance, production and activity were lower in the $\mathrm{K}$ treatment, but there were also some differences in the other 3 treatments. Bacterial production was highest in the Si treatment, abundance was highest in the U treatment (at least after Day 4), and flagellates were also more abundant in the $\mathrm{Si}$ treatment. Interestingly, in some treatments (i.e. U) we had high bacterial production but without a significant increase in chlorophyll concentration (Fig. 2A,D), indicating that bacteria were likely the microbes using the added urea. In consequence, and also given the $>1$-fold difference observed between

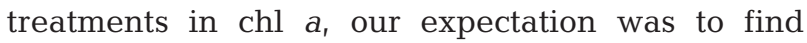
strong differences in bacterial community structure.

The DGGE technique has been widely used in comparative microbial ecology to assess the responses of microbial community structure in changing environments (e.g. MacNaughton et al. 1999, Castle et al. 2006, Labbé et al. 2007). Our analyses indicated that the samples from amended tanks clustered according to the different incubation times, and not according to the treatment. The ANOSIM determined good clustering of samples by the factor time $(\mathrm{R}=0.517, \mathrm{p}=$ 0.003), although the control-sample cluster separated from the rest of the treatments $(\mathrm{R}=0.549, \mathrm{p}=0.001)$. A significant correlation was observed between community composition and time $(\mathrm{R}=0.500, \mathrm{p}=0.004)$. Thus, in spite of the observed changes in phytoplankton biomass caused by the different nutrients added, bacteria changed much less in terms of community structure. We suggest that changes in bacterial community structure were mostly driven by the initial $\mathrm{P}$ limitation and posterior selection by flagellate predation. The NMDS plot (Fig. 6C) started to show a differentiation of bacterial composition after Day 8 in the amended tanks. This is when phytoplankton species composition presented different patterns for each treatment (Table 2).

To what extent bacterial communities are characteristic of the algal community with which they grow 
is an unsolved issue with contrasting results. Grossart et al. (2005) found a strong correspondence between algal species and bacterial abundance and community structure. Our results provide evidence that the bacterial communities developing in the different tanks were relatively independent of the added nutrient type except, perhaps, in the Si treatment (Table 3), which was the only treatment that presented a specific bacterial phylotype. These results differ from those we encountered in similar experiments performed earlier, one in which $\mathrm{P}$ and glucose were added alone and in combination (Allers et al. 2007), and another in which all nutrients were added simultaneously (Pinhassi et al. 2004). In both cases, we found effects of the treatments on the bacterial communities. In some cases, it was clear that exposure to turbulence (one of the manipulations carried out in those experiments) produced clear shifts in phytoplankton community composition followed by changes in bacterioplankton community composition (Pinhassi et al. 2004). Thus, and comparing our results here to those of Pinhassi et al. (2004), it appears that the changes caused by nutrient additions are less influential upon bacterioplankton composition than those created by physical phenomena.

HNF are assumed to be the primary grazers of bacteria and, as such, an important effect of HNF on bacterial community structure could be expected. Previous studies have suggested that both nutrients and grazing play a key role in shaping the genotypic and phenotypic composition of bacterial communities (Lebaron et al. 1999, Pernthaler \& Amann 2005). Since in our study bacterial abundance and activity showed strong differences between treatments in the second bacterial peak (Days 6 to 8), grazing pressure seemed to be important in the shift of the bacterial assemblage from a relatively homogeneous community to a more diversified one (see also the increasing spread of the points as time advances in Fig. 6C).

Many mesocosm experiments have been performed to investigate the effect of nutrient addition on marine planktonic communities in the Mediterranean Sea (Lebaron et al. 1999, Pinhassi et al. 2004, Olsen et al. 2006, Allers et al. 2007). The input of either phosphorus or nitrogen has often been reported to be important, particularly during stratification periods (Eker-Develi et al. 2006). Some studies in the NW Mediterranean have also found differentiation in the bacterial composition due to the different nutrient additions (Schäfer et al. 2001, Pinhassi et al. 2006), or due to the effect of grazers (Lebaron et al. 1999). Our results concur with those of Allers et al. (2007), i.e. a combination of bottom-up and top-down factors con- trol bacterial succession and growth in this type of experiment. We observed that the initial $\mathrm{P}$ deficit of the bacterial communities strongly determined the evolution of the communities after nutrient additions. After an initial very similar bacterial bloom (similar position of points in the NMDS analysis of Fig. 6C), depleted by HNF grazing activity, we observed that the different nutrients additions only slightly modified bacterial community structure and function. Our results agree with previous studies (e.g. Jürgens \& Matz 2002) which demonstrated that enhanced HNF grazing pressure results in shifts in bacterial community composition. The changes observed were clearer in the Si treatment, as the addition of all potentially limiting nutrients $(\mathrm{Si}, \mathrm{P}, \mathrm{N})$ allowed for the development of a clear phytoplankton bloom, with high chlorophyll and the dominance of 1 diatom species.

Acknowledgements. This work was supported by the NoE Marine Genomics Europe and MARBEF, and by the Spanish projects MODIVUS (CTM2005-04795/MAR) and STORM (CTM2009-09352/MAR). We thank V. Balagué, I. Forn and everyone participating in the Blanes Bay sampling program, particularly M. Sala, F. Not, E. Vázquez-Domínguez, E.L. Sà and C. Rodríguez for various help. The students of the 'Marine Genomics Europe Summer Course on Plankton Bloom Dynamics' also provided feedback, and we particularly thank F. Gómez for a first appraisal of phytoplankton diversity.

\section{LITERATURE CITED}

Agawin NSR, Duarte CM, Agustí S, Vaqué D (2004) Effect of $\mathrm{N}: \mathrm{P}$ ratios on response of Mediterranean picophytoplankton to experimental nutrient inputs. Aquat Microb Ecol 34:57-67

Allen JT, Brown L, Sanders R, Moore CM and others (2005) Diatom carbon export enhanced by silicate upwelling in the northeast Atlantic. Nature 437:728-732

Allers E, Gómez-Consarnau L, Pinhassi J, Gasol JM, Šimek K, Pernthaler J (2007) Response of Alteromonadaceae and Rhodobacteriaceae to glucose and phosphorus manipulation in marine mesocosms. Environ Microbiol 9: 2417-2429

Arin L, Marrasé C, Maar M, Peters F, Sala MM, Alcaraz M (2002) Combined effects of nutrients and small-scale turbulence in a microcosm experiment. I. Dynamics and size distribution of osmotrophic plankton. Aquat Microb Ecol 29:51-61

Bell WH (1983) Bacterial utilization of algal extracellular products. 3 . The specificity of algal-bacterial interaction. Limnol Oceanogr 28:1131-1143

Berdalet E, Marrasé C, Estrada M, Arin L, McLean ML (1996) Microbial community responses to nitrogen- and phosphorus-deficient nutrient inputs: microplankton dynamics and biochemical characterization. J Plankton Res 18:1627-1641

Bird DF, Kalff J (1984) Empirical relationships between bacterial abundance and chlorophyll concentration in fresh 
and marine waters. Can J Fish Aquat Sci 41:1015-1023

Castle DM, Montgomery MT, Kirchman DL (2006) Effects of naphthalene on microbial community composition in the Delaware estuary. FEMS Microbiol Ecol 56:55-63

> Clarke KR, Green RH (1988) Statistical design and analysis for a 'biological effects' study. Mar Ecol Prog Ser 46: 213-226

$>$ Coble PG, Del Castillo CE, Avril B (1998) Distribution and optical properties of CDOM in the Arabian Sea during the 1995 Southwest Monsoon. Deep-Sea Res II 45: 2195-2223

Cole JJ, Finlay S, Pace ML (1988) Bacterial production in fresh and saltwater ecosystems: a cross-system overview. Mar Ecol Prog Ser 43:1-10

Cullen JJ, Franks PJ, Karl DM, Longhurst A (2002) Physical influences on marine ecosystem dynamics. In: Robinson AR, McCarthy JJ, Rothschild BJ (eds) The sea, Vol 12. John Wiley \& Sons, New York, NY, p 297-336

Eker-Develi E, Kideys AE, Tugrul S (2006) Role of Saharan dust on phytoplankton dynamics in the northeastern Mediterranean. Mar Ecol Prog Ser 314:61-75

Falcioni T, Papa S, Gasol JM (2008) Evaluating the flow cytometric Nucleic Acid Double Staining Protocol (NADS) in realistic planktonic bacterial death situations. Appl Environ Microbiol 74:1767-1779

Garcés E, Vila M, Rene A, Alonso-Sáez L and others (2007) Natural bacterioplankton assemblage composition during blooms of Alexandrium spp. (Dinophyceae) in NW Mediterranean coastal waters. Aquat Microb Ecol 46: 55-70

$>$ Gasol JM (1994) A framework for the assessment of topdown vs bottom-up control of heterotrophic nanoflagellate abundance. Mar Ecol Prog Ser 113:291-300

Gasol JM, Arístegui J (2007) Cytometric evidence reconciling the toxicity and usefulness of CTC as a marker of bacterial activity. Aquat Microb Ecol 46:71-83

Gasol JM, del Giorgio PA (2000) Using flow cytometry for counting natural planktonic bacteria and understanding the structure of planktonic bacterial communities. Sci Mar 64:197-224

- Gasol JM, Duarte CM (2000) Comparative analyses in aquatic microbial ecology: How far do they go? FEMS Microbiol Ecol 31:99-106

Glibert PM, Azanza R, Burford M, Furuya K and others (2008) Ocean urea fertilization for carbon credits poses high ecological risks. Mar Pollut Bull 56:1049-1056

Grégori G, Citterio S, Ghiani A, Labra M, Sgorbati S, Brown S, Denis M (2001) Resolution of viable and membranecompromised bacteria in freshwater and marine waters based on analytical flow cytometry and nucleic acid double staining. Appl Environ Microbiol 67:4662-4670

Grossart HP, Levold F, Allgaier M, Simon M, Brinkhoff T (2005) Marine diatom species harbour distinct bacterial communities. Environ Microbiol 7:860-873

Guillard RRL (1975) Culture of phytoplankton for feeding marine invertebrates. In: Smith WL, Chanley $\mathrm{MH}$ (eds) Culture of marine invertebrate animals. Plenum Press, New York, NY, p 26-60

Hallegraeff GM (1993) Review of harmful algal blooms and their apparent global increase. Phycologia 32:79-99

> Jürgens K, Matz C (2002) Predation as a shaping force for the phenotypic and genotypic composition of planktonic bacteria. Antonie Leeuwenhoek 81:413-434

Keller AA, Rice RL (1989) Effects of nutrient enrichment on natural populations of the brown tide phytoplankton
Aureococcus anophagefferens (Chrysophyceae). Phycologia 25:636-646

Kirchman DL, Knees E, Hodson R (1985) Leucine incorporation and its potential as a measure of protein synthesis by bacteria in natural aquatic systems. Appl Environ Microbiol 49:599-607

Kruskal JB, Wish M (1979) Multidimensional scaling. Wiley, Beverly Hills, CA

Labbé D, Margesin R, Schinner F, Whyte LG, Greer CW (2007) Comparative phylogenetic analysis of microbial communities in pristine and hydrocarbon-contaminated Alpine soils. FEMS Microbiol Ecol 59:466-475

Lebaron P, Servais P, Troussellier M, Courties C and others (1999) Changes in bacterial community structure in seawater mesocosms differing in their nutrient status. Aquat Microb Ecol 19:255-267

> MacNaughton SJ, Stephen JR, Venosa AD, Davis GA, Chang YJ, White DC (1999) Microbial population changes during bioremediation of an experimental oil spill. Appl Environ Microbiol 65:3566-3574

Marie D, Partensky F (2006) Analyse de micro-organismes marins. In: Ronot X, Grunwald D, Mayol JF, Boutonnat J (eds) La cytométrie en flux. Lavoisier, Cachan, p 211-233

Morán XAG, Estrada M, Gasol JM, Pedrós-Alió C (2002) Dissolved primary production and the strength of phytoplankton-bacterioplankton coupling in contrasting marine regions. Microb Ecol 44:217-223

Myklestad SM (2000) Dissolved organic carbon from phytoplankton. In: Wangersky P (ed) The handbook of environmental chemistry. Marine chemistry, Vol 5D. Springer, Berlin, p 111-148

Olsen Y, Agustí S, Andersen T, Duarte CM and others (2006) A comparative study of responses in planktonic food web structure and function in contrasting European coastal waters exposed to experimental nutrient addition. Limnol Oceanogr 51:488-503

Pernthaler J, Amann R (2005) Fate of heterotrophic microbes in pelagic habitats: focus on populations. Microbiol Mol Biol Rev 69:440-461

> Pinhassi J, Sala MM, Havskum H, Peters F, Guadayol O, Malits A, Marrasé C (2004) Changes in bacterioplankton composition under different phytoplankton regimens. Appl Environ Microbiol 70:6753-6766

Pinhassi J, Gómez-Consarnau L, Alonso-Sáez L, Sala MM, Vidal M, Pedrós-Alió C, Gasol JM (2006) Seasonal changes in bacterioplankton nutrient limitation and their effects on bacterial community composition in the NW Mediterranean Sea. Aquat Microb Ecol 44:241-252

Romera-Castillo C, Sarmento H, Álvarez-Salgado XA, Gasol JM, Marrasé C (2010) Production of chromophoric dissolved organic matter by marine phytoplankton. Limnol Oceanogr 55:446-454

Romera-Castillo C, Sarmento H, Álvarez-Salgado XA, Gasol JM, Marrasé C (2011) Net production/consumption of fluorescent coloured dissolved organic matter by natural bacterial assemblages growing on marine phytoplankton exudates. Appl Environ Microbiol 77:7490-7498

> Rose JM, Caron DA, Sieracki ME, Poulton N (2004) Counting heterotrophic nanoplanktonic protists in cultures and aquatic communities by flow cytometry. Aquat Microb Ecol 34:263-277

Rosenberg R, Elmgren R, Fleischer S, Jonsson P, Persson G, Dahlin H (1990) Marine eutrophication case studies in Sweden. Ambio 19:102-108

Sala MM, Peters F, Gasol JM, Pedrós-Alió C, Marrasé C, 
Vaqué D (2002) Seasonal and spatial variations in the nutrient limitation of bacterioplankton growth in the northwestern Mediterranean. Aquat Microb Ecol 27: 47-56

Sapp M, Wichels A, Gerdts G (2007a) Impacts of cultivation of marine diatoms on the associated bacterial community. Appl Environ Microbiol 73:3117-3120

Sapp M, Schwaderer AS, Wiltshire KH, Hoppe HG, Gerdts G, Wichels A (2007b) Species-specific bacterial communities in the phycosphere of microalgae? Microb Ecol 53:683-699

Schäfer H, Bernard L, Courties C, Lebaron P and others (2001) Microbial community dynamics in Mediterranean nutrient-enriched seawater mesocosms: changes in the genetic diversity of bacterial populations. FEMS Microbiol Ecol 34:243-253

Schauer M, Massana R, Pedrós-Alió C (2000) Spatial differences in bacterioplankton composition along the Catalan coast (NW Mediterranean) assessed by molecular fingerprinting. FEMS Microbiol Ecol 33:51-59

Schauer M, Balagué V, Pedrós-Alió C, Massana R (2003) Seasonal changes in the taxonomic composition of bacterioplankton in a coastal oligotrophic system. Aquat Microb Ecol 31:163-174

Sherr BF, del Giorgio P, Sherr EB (1999) Estimating abundance and single-cell characteristics of respiring bacteria via the redox dye CTC. Aquat Microb Ecol 18:117-131

Sieracki ME, Cucci TL, Nicinski J (1999) Flow cytometric analysis of 5-cyano-2,3-ditolyl tetrazolium chloride activity of marine bacterioplankton in dilution cultures. Appl Environ Microbiol 65:2409-2417

Simon M (1985) Specific uptake rates of amino acids by attached and free-living bacteria in a mesotrophic lake. Appl Environ Microbiol 49:1254-1259

Smayda TJ (1990) Novel and nuisance phytoplankton

Editorial responsibility: Matthias Seaman, Oldendorf/Luhe, Germany blooms in the sea: evidence for a global epidemic. In: Granéli E, Sundström B, Edler L, Anderson DM (eds) Toxic marine phytoplankton. Elsevier, New York, NY, p 29-40

Smayda TJ, Reynolds CS (2001) Community assembly in marine phytoplankton: application of recent models to harmful dinoflagellate blooms. J Plankton Res 23: $447-461$

Smayda TJ, Villareal TA (1989) The 1985 'brown-tide' and the open phytoplankton niche in Narragansett Bay during summer. In: Cosper EM, Bricelj VM, Carpenter EJ (eds) Novel phytoplankton blooms: causes and impacts of recurring brown tides and other unusual blooms. Springer Verlag, Berlin, p 159-187

Smith DC, Azam F (1992) A simple, economical method for measuring bacterial protein synthesis rates in seawater using ${ }^{3} \mathrm{H}$-leucine. Mar Microb Food Webs 6:107-114

Solomon CM, Collier JL, Berg GM, Glibert PM (2010) Role of urea in microbial metabolism in aquatic systems: a biochemical and molecular review. Aquat Microb Ecol 59:67-88

- Tada Y, Taniguchi A, Nagao I, Miki T, Uematsu M, Tsuda A, Hamasaki K (2011) Differing growth responses of major phylogenetic groups of marine bacteria to natural phytoplankton blooms in the western North Pacific Ocean. Appl Environ Microbiol 77:4055-4065

> Thingstad TF, Lignell R (1997) Theoretical models for the control of bacterial growth rate, abundance, diversity and carbon demand. Aquat Microb Ecol 13:19-27

Thingstad F, Zweifel UL, Rassoulzadegan F (1998) P limitation of heterotrophic bacteria and phytoplankton in the northwest Mediterranean. Limnol Oceanogr 43:88-94

Utermöhl H (1958) Zur Vervollkommnung der quantitativen Phytoplankton-Methodik. Mitt Int Ver Theor Angew Limnol 9:1-38

Submitted: August 20, 2010; Accepted: November 4, 2011 Proofs received from author(s): February 10, 2012 